\title{
PATH ANALYSIS ON THE DETERMINANTS OF HOSPITAL LOST UNDER INA-CBGS REIMBURSEMENT FOR PATIENT WITH DENGUE HEMORRHAGIC FEVER IN NGAWI REGIONAL PUBLIC HOSPITAL, EAST JAVA
}

\author{
Betty Nurizky Ariwardani'), Didik Gunawan Tamtomo²), Bhisma Murti') \\ 1) Masters Program in Public Health, Universitas Sebelas Maret \\ ${ }^{2}$ Department of Anatomy, Faculty of Medicine, Universitas Sebelas Maret
}

\begin{abstract}
Background: Hospitals are demanded to be more efficient and effective in providing medical services to avoid losses in the era of National Health Insurance. The increase in cases of dengue hemorrhagic fever (DHF) is a burden on the cost of medical services in Indonesia. This study aimed to examine the determinants of hospital lost under Indonesia Case-Based Groups (INACBGs) reimbursement for patients with dengue hemorrhagic fever (DHF).

Subjects and Method: A cross-sectional study was carried out at dr. Soeroto hospital, Ngawi, East Java, from September to October 2019. A sample of 200 in-patients was selected by simple random sampling. The dependent variable was tariff difference between INA-CBGs and hospital cost. The independent variables were class of treatment, length of stay, blood transfusion, co-morbidity, and complication. The data were obtained from DHF in-patients' medical record. The data were analyzed by path analysis model run on Stata 13 .

Results: Tariff difference was directly and positively affected by length of stay $(b=2.77 ; 95 \%$ $\mathrm{CI}=1.78$ to $3.75 ; \mathrm{p}<0.001)$, blood transfusion $(\mathrm{b}=2.95 ; 95 \% \mathrm{CI}=0.36$ to $5.54 ; \mathrm{p}=0.025)$, patients age $(b=0.09 ; 95 \% \mathrm{CI}=-1.52$ to $1.71 ; \mathrm{p}=0.907)$, co-morbidity $(\mathrm{b}=0.58 ; 95 \% \mathrm{CI}=-1.07$ to $2.22 ; \mathrm{p}=0.491)$, and complication $(\mathrm{b}=0.34 ; 95 \% \mathrm{CI}=-1.69$ to $2.36 ; \mathrm{p}=0.743)$. Tariff difference was directly and negatively affected by type of treatment $(b=-0.81 ; 95 \% \mathrm{CI}=\mathbf{- 2 . 0 2}$ to $0.40 ; \mathrm{p}=0.191)$. Tariff difference was indirectly affected by co-morbidity, complication, class of treatment, and patient age.

Conclusion: Tariff difference is directly and positively affected by length of stay, blood transfusion, patient age, co-morbidity, and complication. Tariff difference is directly and negatively affected by type of treatment. Tariff difference is indirectly affected by comorbidity, complication, class of treatment, and patient age.
\end{abstract}

Keywords: INA CBGs, hospital tariff, care cost, dengue hemorrhagic fever

\section{Correspondence:}

Betty Nurizky Ariwardani. Masters Program in Public Health, Universitas Sebelas Maret, Jl. Ir. Sutami 36A, Surakarta, Central Java, Indonesia. Email: bettyna175@-gmail.com. Mobile: o82233243164.

The $7^{\text {th }}$ International Conference on Public Health Solo, Indonesia, November 18-19, 2020 | 350 https://doi.org/10.26911/the7thicph.04.35 